\title{
(E)-2,6,10-Trimethyldodec-8-en-2-ol: An Undescribed Sesquiterpenoid from Copaiba Oil
}

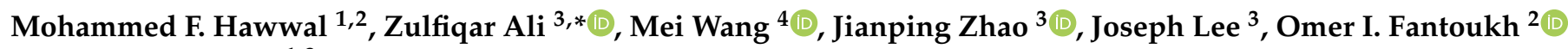 \\ and Ikhlas A. Khan 1,3,* \\ 1 Department of BioMolecular Sciences, Division of Pharmacognosy, School of Pharmacy, The University of \\ Mississippi, University, MS 38677, USA; mhawwal@ksu.edu.sa \\ 2 Department of Pharmacognosy, College of Pharmacy, King Saud University, Riyadh 4545, Saudi Arabia; \\ ofantoukh@ksu.edu.sa \\ 3 National Center for Natural Products Research, School of Pharmacy, The University of Mississippi, \\ University, MS 38677, USA; jianping@olemiss.edu (J.Z.); jclee1@olemiss.edu (J.L.) \\ 4 Natural Products Utilization Research Unit, Agricultural Research Service, U.S. Department of Agriculture, \\ University, MS 38677, USA; meiwang@olemiss.edu \\ * Correspondence: zulfiqar@olemiss.edu (Z.A.); ikhan@olemiss.edu (I.A.K.); \\ Tel.: +1-(662)9151090 (Z.A. \& I.A.K.)
}

Citation: Hawwal, M.F.; Ali, Z.; Wang, M.; Zhao, J.; Lee, J.; Fantoukh, O.I.; Khan, I.A. (E)-2,6,10-

Trimethyldodec-8-en-2-ol: An Undescribed Sesquiterpenoid from Copaiba Oil. Molecules 2021, 26, 4456. https://doi.org/10.3390/

molecules26154456

Academic Editor: Thomas J. Schmidt

Received: 14 May 2021

Accepted: 19 July 2021

Published: 23 July 2021

Publisher's Note: MDPI stays neutral with regard to jurisdictional claims in published maps and institutional affiliations.

Copyright: (c) 2021 by the authors. Licensee MDPI, Basel, Switzerland. This article is an open access article distributed under the terms and conditions of the Creative Commons Attribution (CC BY) license (https:// creativecommons.org/licenses/by/ $4.0 /)$.

\begin{abstract}
The use of copaiba oil has been reported since the 16th century in Amazon traditional medicine, especially as an anti-inflammatory ingredient and for wound healing. The use of copaiba oil continues today, and it is sold in various parts of the world, including the United States. Copaiba oil contains mainly sesquiterpenes, bioactive compounds that are popular for their positive effect on human health. As part of our ongoing research endeavors to identify the chemical constituents of broadly consumed herbal supplements or their adulterants, copaiba oil was investigated. In this regard, copaiba oil was subjected to repeated silica gel column chromatography to purify the compounds. As a result, one new and seven known sesquiterpenes/sesquiterpenoids were isolated and identified from the copaiba oil. The new compound was elucidated as (E)-2,6,10-trimethyldodec8-en-2-ol. Structure elucidation was achieved by 1D- and 2D NMR and GC/Q-ToF mass spectral data analyses. The isolated chemical constituents in this study could be used as chemical markers to evaluate the safety or quality of copaiba oil.
\end{abstract}

Keywords: copaiba oil; Copaifera; Fabaceae; new sesquiterpenoid; sesquiterpenes; NMR

\section{Introduction}

European settlers reported that the people of the Brazilian Amazon region used copaiba trees to treat their wounds [1]. Marcgraf and Piso were the first to describe the copaiba tree in 1638 [2]. Amazonians use copaiba oil resin as an anti-inflammatory and healing agent [3]. Copaiba oil is obtained by tapping the trunk of the Copaifera tree. Copaiba oil can be obtained from several species of Copaifera trees, but Copaifera reticulata is responsible for $70 \%$ of oil production [4,5]. Copaifera trees belong to the family Fabaceae (Leguminosae) [4]. Copaifera trees range from 0.5 to $5 \mathrm{~m}$ in diameter and up to $60 \mathrm{~m}$ in height, and can live up to 400 years [4]. Copaiba oil is an exudate secretion that results from the trees' detoxification process. The secretion acts as a defensive mechanism against ordinary predators, such as fungi and bacteria [6]. South America, particularly Brazil, has diverse Copaifera species and is considered the largest global exporter of copaiba oil.

Copaiba oil has been used in folk medicine for centuries as a wound-healing agent [7]. This use was likely inspired by animals, as the indigenous people observed injured animals rubbing their bodies on the stem of Copaifera trees [4]. The indigenous people of the Amazon region also used the Copaifera tree to treat several other conditions, such as urinary tract infections, sore throats, stomach ulcers, and infectious diseases. Copaifera trees play a vital role as an alternative remedy in the Amazon region of Brazil, and it is no surprise 
that phytotherapeutic and cosmetic products using copaiba oil have found their way not only into the Brazilian market but also to the international markets [1]. The main chemical constituent of copaiba oil is $\beta$-caryophyllene, which can be found in various essential oils [8]. The chemical profile of copaiba oil might be slightly different from one species to another, but in general, the main constituents are $\beta$-caryophyllene, $\alpha$-humulene, $\alpha$-copaene, $\alpha$-bergamotene, $\delta$-cadiene, and $\beta$-bisabolol. Some copaiba oils contain diterpene acids, such as copalic acid, clorechinic acid, and hardwickiic acid [4]. However, several factors might cause chemical composition variation in copaiba oil, such as seasonal and climatic characteristics of the environment, soil type, and composition, rainfall index, and species genetics $[4,5]$. In this study, copaiba oil was investigated as part of a continuing effort to isolate and identify chemical markers for use in quality studies of dietary supplements and botanical drug products under development in the United States. In this regard, eight sesquiterpenes/sesquiterpenoids (Figure 1), including one new, were isolated and characterized by analyzing their 1D and 2D NMR and GC/Q-ToF mass data.<smiles>CCC(C)C=CCC(C)CCCC(C)(C)O</smiles>

1<smiles>CC1(C)[C@H]2CC[C@]3(C)CCC[C@](C)(O)[C@@H]3[C@H]21</smiles>

5

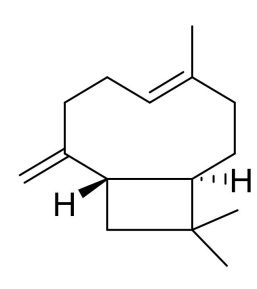

2<smiles>CC1=C[C@H]2C(C(C)C)CC[C@H](O)[C@H]2CC1</smiles>

6<smiles>CCCC(C)=CCC(C)=CCC(C)(C)C</smiles>

3<smiles>CC1=C[C@H]2C(C(C)C)CC[C@H](O)[C@]2(C)CC1</smiles>

7<smiles>C=C1CCCC2(O)CCC3C2C(CC3(C)C)C1C</smiles>

4<smiles>CC1=C[C@]2(CCC1)[C@@H](C)CC[C@@H](C(C)C)[C@H]2O</smiles>

8

Figure 1. Chemical structures of the isolated compounds.

\section{Results and Discussion}

Copaiba oil was fractionated via silica gel column chromatography into three fractions. Compounds 2-4 were obtained from fraction A and 5-8 were purified from fraction B. Due to the limited amount and complexity of fraction C, only one compound (1) could be isolated from it. Compound $\mathbf{1}$ was obtained as a colorless oil. Its molecular formula, $\mathrm{C}_{15} \mathrm{H}_{30} \mathrm{O}$, was established based on the $\left[\mathrm{M}-\mathrm{H}_{2} \mathrm{O}\right]^{+}$peak at $\mathrm{m} / z 208.2188$ (calcd for $\mathrm{C}_{15} \mathrm{H}_{28}$, $\mathrm{m} / \mathrm{z}$ 208.2191) in the GC/Q-ToF MS. The IR spectrum of $\mathbf{1}$ showed characteristic bands for alkene $\left(1709 \mathrm{~cm}^{-1}\right)$ and hydroxyl groups $\left(3400 \mathrm{~cm}^{-1}\right)$. The ${ }^{13} \mathrm{C}$ NMR spectrum of 1 revealed 15 signals corresponded to five methyl groups, two olefinic methines, two aliphatic methines, five methylenes, and an oxygenated non-protonated carbon. The ${ }^{1} \mathrm{H}$ NMR spectrum of 1 displayed a singlet of six protons at $1.21 \mathrm{ppm}$ assignable to two tertiary methyl groups $\left(\mathrm{H}_{3}-1\right.$ and $\left.\mathrm{H}_{3}-13\right)$, a triplet $(J=7.4 \mathrm{~Hz})$ of three protons at $0.84 \mathrm{ppm}$ typical for a primary methyl group $\left(\mathrm{H}_{3}-12\right)$, and two characteristic doublets of three protons each $(J=6.6 \mathrm{~Hz}$ and $J=6.8 \mathrm{~Hz})$ at $0.86 \mathrm{ppm}$ and $0.95 \mathrm{ppm}$ for secondary methyl groups $\left(\mathrm{H}_{3}-14\right.$ and $\left.\mathrm{H}_{3}-15\right)$. A trans double inferred from two typical olefin resonances at $\delta_{\mathrm{H}} 5.24(\mathrm{dd}$, $J=15.4,7.5 \mathrm{~Hz})$ and $5.32(\mathrm{dt}, J=15.4,7.5)$. The proton resonances were connected to their respective carbons with the help of HSQC spectrum (Table 1). The locations of the 
hydroxy and two tertiary methyl groups at C-2 were supported by the HMBC correlations of methyl protons $\left(\delta_{\mathrm{H}} 1.20\right)$ with C-2 $\left(\delta_{\mathrm{C}} 71.23\right)$ and C-3 $\left(\delta_{\mathrm{C}} 44.41\right)$. Similarly, the positions of other methyl groups, double bond, methylenes, and methines were confirmed by the $\mathrm{HMBC}$ correlations and ${ }^{1} \mathrm{H}^{-1} \mathrm{H}$ COSY couplings (Figure 2). Due to the acyclic nature of the molecule, the absolute configurations at C-6 and C-10 could not be determined. The ${ }^{1} \mathrm{H}$ and ${ }^{13} \mathrm{C}$ NMR data assignments were carried out by COSY, HSQC, and HMBC NMR data analyses, and compound $\mathbf{1}$ was ultimately elucidated as a sesquiterpenoid named $(E)-2,6$, 10-trimethyldodec-8-en-2-ol. To the best of our knowledge, compound $\mathbf{1}$ was found to be a new molecule based on a SciFinder database search.

Table 1. ${ }^{13} \mathrm{C}$ NMR (125 MHz) and ${ }^{1} \mathrm{H}$ NMR (500 MHz) spectral data of $\mathbf{1}$ in $\mathrm{CDCl}_{3}$.

\begin{tabular}{ccc}
\hline No & $\delta_{\mathrm{C}}$ & $\delta_{\mathrm{H},}$ mult. $(\boldsymbol{J}$ in Hz) \\
\hline 1 & 29.37 & $1.21, \mathrm{~s}$ \\
2 & 71.23 & - \\
3 & 44.41 & $1.40, \mathrm{~m}$ \\
& & $1.45, \mathrm{~m}$ \\
4 & 21.96 & $1.32, \mathrm{~m}$ \\
& & $1.38, \mathrm{~m}$ \\
5 & 37.19 & $1.11, \mathrm{~m}$ \\
6 & 33.34 & $1.31, \mathrm{~m}$ \\
7 & 40.23 & $1.45, \mathrm{~m}$ \\
8 & 127.10 & $1.82, \mathrm{dt}(14.0,7.5)$ \\
9 & 137.74 & $2.00, \mathrm{dt}(14.0,7.5)$ \\
10 & 38.69 & $5.32, \mathrm{dt}(15.4,7.5)$ \\
11 & 30.05 & $5.24, \mathrm{dd}(15.4,7.5)$ \\
12 & 11.97 & $1.96, \mathrm{~m}$ \\
13 & 29.42 & $1.26, \mathrm{~m}$ \\
14 & 19.62 & $0.84, \mathrm{~m}(7.4)$ \\
15 & 20.73 & $1.21, \mathrm{~s}$ \\
& & $0.86, \mathrm{~d}(6.6)$ \\
& & $0.95, \mathrm{~d}(6.8)$ \\
\hline
\end{tabular}

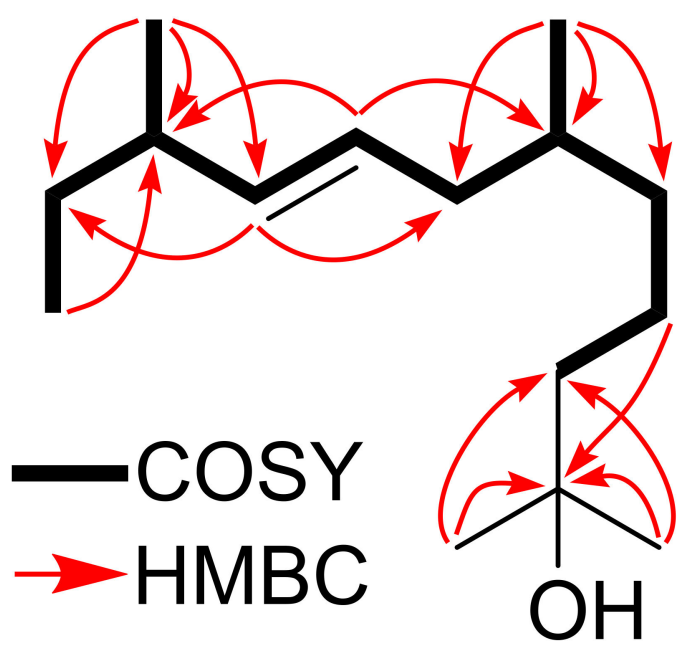

Figure 2. COSY couplings and key HMBC correlations of compound 1.

Previously described compounds (Figure 1) were identified via their 1D and 2D NMR and mass data analyses, which were in agreement with those reported in the literature, as $\beta$-caryophyllene (2) [9], $\alpha$-humulene (3) [10], caryophyllene oxide (4) [11], malliol (5) [12], T-cadinol (6) [13], T-muurolol (7) [14] and torreyol (8) [15]. GC/MS analysis of the investigated copaiba oil showed the following percent composition of the aforementioned compounds: $0.01 \%(E)$-2,6,10-trimethyldodec-8-en-2-ol (1), 38.58\% $\beta$-caryophyllene (2), 
$6.26 \% \alpha$-humulene (3), 0.02\% caryophyllene oxide (4), $0.04 \%$ malliol (5), $0.12 \%$ T-cadinol (6), $0.16 \%$ T-muurolol (7), and 0.12\% torreyol (8) (Supplementary Materials Figure S1). Quantitative analysis was determined as the peak area percentage utilizing the total ion chromatogram (TIC).

Several biological activities have been reported for the isolated compounds. $\beta$ caryophyllene (2) has been associated with numerous biological activities, such as anticarcinogenic, antibiotic, and anti-inflammatory [16]. Anti-inflammatory properties of $\alpha$-humulene (3) have also been evaluated [17], revealing that oral administration of $\alpha$ humulene (3) produces significant inhibitory effects in multiple mouse and rat models. Caryophyllene oxide (4) exhibited anti-inflammatory, analgesic [18], and antifungal activities [19]. Essential oil from P. cylindraceus containg 42\% maaliol (5) demonstrated significant cytotoxic activity against three cancerous cell lines (Hela, HepG2, and HT-29) [20]. T-cadinol (6) produced smooth-muscle relaxant effects on isolated guinea pig ileum, depending on the dosage [21]. T-Muurolol (7) showed remarkable antifungal and antitermitic activity [22]. Torreyol (8) revealed antiproliferative and cytotoxic activities [23].

\section{Materials and Methods}

\subsection{General Procedures}

NMR spectra were measured on a Bruker AU III 500 MHz NMR spectrometer (Bruker, Billerica, MA, USA) and chemical shifts were referenced to the residual solvent signals. IR spectrum was carried out on Agilent Technologies Cary 630 FTIR (Agilent Technologies, Santa Clara, CA, USA). GC/Q-ToF mass data were recorded on an Agilent 7890 GC and the Agilent 7250 Accurate-Mass Quadrupole Time-of-Flight mass spectrometer equipped with an electron ionization source operated with an electron energy of $70 \mathrm{eV}$. The data were acquired utilizing Agilent MassHunter software (version B7.06.274). Flash silica gel (32-63 $\mu$, Dynamic Adsorbents Inc, Norcross, GA, USA) was used as an adsorbent in column chromatography (CC). TLC was performed on silica gel $\mathrm{F}_{254}$ aluminum sheet $(20 \times 20 \mathrm{~cm})$ (Sorbent Tech., Norcross, GA, USA). Spots were visualized on TLC by spraying with $0.5 \%$ vanillin (Sigma, St. Louis, MO, USA) solution in conc. $\mathrm{H}_{2} \mathrm{SO}_{4}-\mathrm{EtOH}(5: 95)$ followed by heating. Analytical grade solvents (Fisher Chemicals, Hampton, NH, USA) were used for purification.

\subsection{Plant Material}

The copaiba oil obtained from Copaifera officinalis L. was provided by doTERRA (Pleasant Grove, UT, USA). A reference sample \# 613 was deposited in the product repository at the National Center for Natural Products Research (NCNPR), University of Mississippi.

\subsection{Extraction and Isolation}

The oil (13.3 g) was subjected to column chromatography (CC) over silica gel $(105 \mathrm{~cm} \times 5 \mathrm{~cm})$ using a stepwise gradient concentration of solvents system starting with $100 \%$ hexanes ( $3 \mathrm{~L}$ ) followed by increasing polarity with ethyl acetate till $30 \%$ ethyl acetate was reached $(10 \%$ ethyl acetate $(1.5 \mathrm{~L}), 10 \%$ ethyl acetate $(1.5 \mathrm{~L})$, and $10 \%$ ethyl acetate $(1 \mathrm{~L})$ ). Based on TLC profile, the resulting fractions were merged into three collective fractions (A, B, and C). Fraction A (8.5 g) was applied to CC over silica gel $(105 \mathrm{~cm} \times 4 \mathrm{~cm})$ using hexanes/ethyl acetate $(100: 0(1.5 \mathrm{~L}), 97: 3(1 \mathrm{~L})$, and 95:5 $(1 \mathrm{~L}))$ to yield 23 fractions (A1-A23). $\beta$-Caryophyllene $(2,700 \mathrm{mg})$ from Fr. A6, $\alpha$-humulene (3, $12 \mathrm{mg})$ from Fr. A10, and caryophyllene oxide (4,13.5 mg) from Fr. A15 were purified by CC over silica gel $(85 \mathrm{~cm} \times 3 \mathrm{~cm})$ using mixtures of hexanes/ethyl acetate $(98: 2(1.5 \mathrm{~L}), 97: 3(1.5 \mathrm{~L})$, and 90:10 $(1.5 \mathrm{~L})$, respectively). Fraction B $(2 \mathrm{~g})$ was chromatographed over silica gel $(75 \mathrm{~cm} \times 3 \mathrm{~cm})$ using a mixture of hexanes/ethyl acetate $(90: 10(2 \mathrm{~L}))$ to yield six fractions (B1-B6). T-Cadinol (6, $10.5 \mathrm{mg}$ ) from Fr. B1, T-muurolol (7, $14.4 \mathrm{mg})$ from Fr. B2, and torreyol $(8,9.4 \mathrm{mg})$ from Fr. B3 were obtained by CC over silica gel $(75 \mathrm{~cm} \times 2 \mathrm{~cm})$ using a mixture of hexanes/ethyl acetate $(90: 10,(500 \mathrm{~mL}))$. Fraction B4 was subjected to CC on silica gel $(65 \mathrm{~cm} \times 2 \mathrm{~cm})$ using hexanes/ethyl acetate $(80: 20(400 \mathrm{~mL}))$ mixture to yield 
maaliol (5, $2.5 \mathrm{mg})$. Compound $\mathbf{1}(2.9 \mathrm{mg})$ was obtained from Fr. C (215 mg) by CC over silica gel $(72 \mathrm{~cm} \times 2 \mathrm{~cm})$ with hexanes/ethyl acetate $(70: 30(500 \mathrm{~mL}))$ mixture.

\subsection{Spectral Data}

(E)-2, 6, 10-trimethyldodec-8-en-2-ol (1). Colorless oil. $[\alpha]^{23}{ }_{\mathrm{D}} 66\left(c 0.16, \mathrm{CHCl}_{3}\right)$. IR $\gamma_{\max } \mathrm{cm}^{-1}: 3400,2924,2855,1709,1469,1377,1153,971,907$. NMR data: see Table 1. GC/Q-ToF-MS: $m / z 208.2188$ [M- $\left.\mathrm{H}_{2} \mathrm{O}\right]^{+}$(calcd for $\mathrm{C}_{15} \mathrm{H}_{28}, \mathrm{~m} / z$ 208.2191), $179.1794\left[\mathrm{C}_{13} \mathrm{H}_{23}\right]^{+}$, 123.1168 $\left[\mathrm{C}_{9} \mathrm{H}_{15}\right]^{+}, 109.1012\left[\mathrm{C}_{8} \mathrm{H}_{13}\right]^{+}, 95.0855\left[\mathrm{C}_{7} \mathrm{H}_{11}\right]^{+}, 81.0699\left[\mathrm{C}_{6} \mathrm{H}_{9}\right]^{+}, 69.0699\left[\mathrm{C}_{5} \mathrm{H}_{9}\right]^{+}$, $67.0542\left[\mathrm{C}_{5} \mathrm{H}_{7}\right]^{+}, 55.0542\left[\mathrm{C}_{4} \mathrm{H}_{7}\right]^{+}, \mathrm{m} / z 41.0386\left[\mathrm{C}_{3} \mathrm{H}_{5}\right]^{+}$.

\subsection{GC/MS Analysis}

For a general analysis of copaiba samples, an Agilent 7890 GC equipped with a 7693 autosampler and an Agilent 5975C quadrupole mass spectrometer was used. Separation was achieved with an Agilent DB-5MS Ultra Inert column $(60 \mathrm{~m} \times 0.25 \mathrm{~mm} \times 0.25 \mu \mathrm{m})$. The inlet was held at $260{ }^{\circ} \mathrm{C}$ and was operated in the split mode with a split ratio of 50:1 and an injection volume of $1 \mathrm{uL}$. The initial GC oven temperature was $80^{\circ} \mathrm{C}$; it was then heated at $3^{\circ} \mathrm{C} / \mathrm{min}$ to $125^{\circ} \mathrm{C}$, then ramped at $1{ }^{\circ} \mathrm{C} / \mathrm{min}$ to $140^{\circ} \mathrm{C}$ and held for $10 \mathrm{~min}$, then heated at $3^{\circ} \mathrm{C} / \mathrm{min}$ to $170^{\circ} \mathrm{C}$, before a final ramp of $8^{\circ} \mathrm{C} / \mathrm{min}$ to $280^{\circ} \mathrm{C}$ held for $10 \mathrm{~min}$ was used. The mass spectrometer was equipped with an electron ionization source, which was operated with an electron energy of $70 \mathrm{eV}$. The ion source, quadrupole, and transfer line temperatures were set to 230,150 , and $280^{\circ} \mathrm{C}$. Mass spectra data were recorded from 35 to $500 \mathrm{~m} / \mathrm{z}$ after a 5 min solvent delay. Data were acquired utilizing Agilent MassHunter software (version B7.06.274). All of the copaiba samples were diluted in dichloromethane $(0.01 \%, v / v)$, and n-dodecane (IS) was added to each sample solution at a constant concentration of $300 \mu \mathrm{g} / \mathrm{mL}$.

In order to obtain the accurate mass of compound 1, analysis was performed utilizing an Agilent 7890B gas chromatographic (GC) instrument which was equipped with a RS185 PAL3 autosampler. The GC was connected to an Agilent 7250 Accurate-Mass Quadrupole Time-of-Flight (Q-ToF) mass spectrometer. The capillary column $(30 \mathrm{~m} \times 0.25 \mathrm{~mm}$ i.d.) utilized was coated with a 5\% Phenyl Methyl Siloxane (J\&W HP-5MS) film $(0.25 \mu \mathrm{m})$. Helium at a constant flow rate of $1 \mathrm{~mL} / \mathrm{min}$ was used as the carrier gas. The following GC oven program was utilized: $50{ }^{\circ} \mathrm{C}$ held for $1 \mathrm{~min}$ and then heated at a rate of $6{ }^{\circ} \mathrm{C} / \mathrm{min}$ to $260^{\circ} \mathrm{C}$. The inlet was programmed at $260^{\circ} \mathrm{C}$ in split mode. A split ratio of $50: 1$ with an injection volume of $0.2 \mathrm{uL}$ was used for compound 1 . The $\mathrm{Q}-\mathrm{ToF}$ mass spectrometer was equipped with a high-emission low-energy electron ionization source which was operated with an electron energy of $70 \mathrm{eV}$ and an emission current of $5.0 \mu \mathrm{A}$. The source, quadrupole, and transfer line temperatures were $230^{\circ} \mathrm{C}, 150^{\circ} \mathrm{C}$, and $260^{\circ} \mathrm{C}$, respectively, during the experiment. All mass spectra data were recorded at a rate of $5 \mathrm{~Hz}$ from 35 to $450 \mathrm{~m} / \mathrm{z}$ after a 4 min solvent delay. Data were acquired utilizing Agilent MassHunter software (version B7.06.274).

\section{Conclusions}

In this study, eight compounds were isolated from the copaiba oil. All compounds were characterized as sesquiterpenes/sesquiterpenoids. Out of them, (E)-2,6,10-trimethyldodec8-en-2-ol (1) was found to be previously undescribed. Possible contribution of the new compound (1) to the biological activity of copaiba oil will have to be investigated in further studies.

Supplementary Materials: The following are available online, Figure S1: GC/MS total ion chromatogram of investigated copaiba oil, Figure S2: ${ }^{1} \mathrm{H}$ NMR spectrum of 1, Figure S3: ${ }^{13} \mathrm{C}$ NMR spectrum of 1, Figure S4: COSY spectrum of 1, Figure S5: HSQC spectrum of 1, Figure S6: HMBC spectrum of 1, Figure S7: IR spectrum of 1, Figure S8: GC/Q-ToF mass spectrum of 1, Figure S9: Tentative mass fragmentation associated with 1 are available online.

Author Contributions: Conceptualization, I.A.K.; methodology, Z.A.; formal analysis, J.L.; investigation, M.F.H. and Z.A.; data curation, M.F.H. and Z.A.; writing-original draft preparation, M.F.H.; writing-review and editing, Z.A. and O.I.F.; supervision, I.A.K.; project administration, M.W., J.Z. 
and Z.A.; funding acquisition, M.W., J.Z. and Z.A. All authors have read and agreed to the published version of the manuscript.

Funding: This research was funded by the United States Department of Agriculture, Agricultural Research Service, Specific Cooperative Agreement (No. 58-6060-6-015) and doTERRA International, Research Agreement.

Institutional Review Board Statement: Not applicable.

Informed Consent Statement: Not applicable.

Data Availability Statement: Not applicable.

Acknowledgments: The authors are thankful to the United States Department of Agriculture, Agricultural Research Service, Specific Cooperative Agreement (No. 58-6060-6-015) and doTERRA International for financial support. Mohammed and Omer extend their appreciation to the Deanship of Scientific Research and the Research Center, College of Pharmacy, King Saud University for financial support.

Conflicts of Interest: The authors declare no conflict of interest.

\section{References}

1. Sachetti, C.G.; de Carvalho, R.R.; Paumgartten, F.J.R.; Lameira, O.A.; Caldas, E.D. Developmental toxicity of copaiba tree (Copaifera reticulata Ducke, Fabaceae) oleoresin in rat. Food Chem. Toxicol. 2011, 49, 1080-1085. [CrossRef] [PubMed]

2. Comar, J.F.; Babeto de Sá-Nakanishi, A.; de Oliveira, A.L.; Marques Nogueira Wendt, M.; Bersani Amado, C.A.; Ishii Iwamoto, E.L.; Peralta, R.M.; Bracht, A. Oxidative state of the liver of rats with adjuvant-induced arthritis. Free Radic. Biol. Med. 2013, 58, 144-153. [CrossRef] [PubMed]

3. Teixeira, F.B.; de Brito Silva, R.; Lameira, O.A.; Webber, L.P.; D'Almeida Couto, R.S.; Martins, M.D.; Lima, R.R. Copaiba oil-resin (Copaifera reticulata Ducke) modulates the inflammation in a model of injury to rats' tongues. BMC Complement. Altern. Med. 2017, 17, 313. [CrossRef]

4. Da Trindade, R.; da Silva, J.K.; Setzer, W.N. Copaifera of the Neotropics: A review of the phytochemistry and pharmacology. Int. J. Mol. Sci. 2018, 19, 1511. [CrossRef] [PubMed]

5. Veiga Junior, V.F.; Rosas, E.C.; Carvalho, M.V.; Henriques, M.G.; Pinto, A.C. Chemical composition and anti-inflammatory activity of copaiba oils from Copaifera cearensis Huber ex Ducke, Copaifera reticulata Ducke and Copaifera multijuga Hayne-a comparative study. J. Ethnopharmacol. 2007, 112, 248-254. [CrossRef]

6. Da Silva, A.G.; Puziol Pde, F.; Leitao, R.N.; Gomes, T.R.; Scherer, R.; Martins, M.L.; Cavalcanti, A.S.; Cavalcanti, L.C. Application of the essential oil from copaiba (Copaifera langsdori Desf.) for acne vulgaris: A double-blind, placebo-controlled clinical trial. Altern. Med. Rev. 2012, 17, 69-75.

7. Arruda, C.; Aldana Mejía, J.A.; Ribeiro, V.P.; Gambeta Borges, C.H.; Martins, C.H.G.; Sola Veneziani, R.C.; Ambrósio, S.R.; Bastos, J.K. Occurrence, chemical composition, biological activities and analytical methods on Copaifera genus-a review. Biomed. Pharmacother. 2019, 109, 1-20. [CrossRef]

8. Ames-Sibin, A.P.; Barizão, C.L.; Castro-Ghizoni, C.V.; Silva, F.M.S.; Sá-Nakanishi, A.B.; Bracht, L.; Bersani-Amado, C.A.; MarçalNatali, M.R.; Bracht, A.; Comar, J.F. $\beta$-Caryophyllene, the major constituent of copaiba oil, reduces systemic inflammation and oxidative stress in arthritic rats. J. Cell. Biochem. 2018, 119, 10262-10277. [CrossRef]

9. Larionov, O.V.; Corey, E.J. An unconventional approach to the enantioselective synthesis of caryophylloids. J. Am. Chem. Soc. 2008, 130, 2954-2955. [CrossRef] [PubMed]

10. McMurry, J.E.; Matz, J.R.; Kees, K.L. Synthesis of macrocyclic terpenoids by intramolecular carbonyl coupling: Flexibilene and humulene. Tetrahedron 1987, 43, 5489-5498. [CrossRef]

11. Reina, M.; Nold, M.; Santana, O.; Orihuela, J.C.; González-Coloma, A. C-5-substituted antifeedant silphinene sesquiterpenes from senecio palmensis. J. Nat. Prod. 2002, 65, 448-453. [CrossRef] [PubMed]

12. Gijsen, H.J.M.; Wijnberg, J.B.P.A.; van Ravenswaay, C.; de Groot, A. Rearrangement reactions of aromadendrane derivatives. The synthesis of (+)-maaliol, starting from natural (+)-aromadendrene-IV. Tetrahedron 1994, 50, 4733-4744. [CrossRef]

13. Labbe, C.; Castillo, M.; Connolly, J.D. Mono and sesquiterpenoids from Satureja gilliesii. Phytochemistry 1993, 34, 441-444. [CrossRef]

14. Ding, L.; Pfoh, R.; Rühl, S.; Qin, S.; Laatsch, H. T-Muurolol sesquiterpenes from the marine Streptomyces sp. M491 and revision of the configuration of previously reported amorphanes. J. Nat. Prod. 2009, 72, 99-101. [CrossRef]

15. Van Eijk, G.W.; Roeijmans, H.J.; Verwiel, P.E.n.J. Isolation and identification of the sesquiterpenoid (+)-torreyol from Xylobolus frustulatus. Exp. Mycol. 1984, 8, 273-275. [CrossRef]

16. Legault, J.; Pichette, A. Potentiating effect of $\beta$-caryophyllene on anticancer activity of $\alpha$-humulene, isocaryophyllene and paclitaxel. J. Pharm. Pharmacol. 2007, 59, 1643-1647. [CrossRef] 
17. Fernandes, E.S.; Passos, G.F.; Medeiros, R.; da Cunha, F.M.; Ferreira, J.; Campos, M.M.; Pianowski, L.F.; Calixto, J.B. Antiinflammatory effects of compounds alpha-humulene and (-)-trans-caryophyllene isolated from the essential oil of Cordia verbenacea. Eur. J. Pharmacol. 2007, 569, 228-236. [CrossRef]

18. Chavan, M.J.; Wakte, P.S.; Shinde, D.B. Analgesic and anti-inflammatory activity of caryophyllene oxide from Annona squamosa L. bark. Phytomedicine 2010, 17, 149-151. [CrossRef]

19. Yang, D.; Michel, L.; Chaumont, J.-P.; Millet-Clerc, J. Use of caryophyllene oxide as an antifungal agent in an in vitro experimental model of onychomycosis. Mycopathologia 2000, 148, 79-82. [CrossRef]

20. Mothana, R.A.; Khaled, J.M.; Noman, O.M.; Kumar, A.; Alajmi, M.F.; Al-Rehaily, A.J.; Kurkcuoglu, M. Phytochemical analysis and evaluation of the cytotoxic, antimicrobial and antioxidant activities of essential oils from three Plectranthus species grown in Saudi Arabia. BMC Complement. Alt. Med. 2018, 18, 237. [CrossRef]

21. Claeson, P.; Andersson, R.; Samuelsson, G. T-cadinol: A pharmacologically active constituent of scented myrrh: Introductory pharmacological characterization and high field ${ }^{1} \mathrm{H}$ - and ${ }^{13} \mathrm{C}-\mathrm{NMR}$ data. Planta Med. 1991, 57, 352-356. [CrossRef] [PubMed]

22. Cheng, S.-S.; Wu, C.-L.; Chang, H.-T.; Kao, Y.-T.; Chang, S.-T. Antitermitic and antifungal activities of essential oil of Calocedrus formosana leaf and its composition. J. Chem. Ecol. 2004, 30, 1957-1967. [CrossRef] [PubMed]

23. Yap, H.-Y.Y.; Muria-Gonzalez, M.J.; Kong, B.-H.; Stubbs, K.A.; Tan, C.-S.; Ng, S.-T.; Tan, N.-H.; Solomon, P.S.; Fung, S.-Y.; Chooi, Y.-H. Heterologous expression of cytotoxic sesquiterpenoids from the medicinal mushroom Lignosus rhinocerotis in yeast. Microb. Cell Fact. 2017, 16, 103. [CrossRef] 